\title{
Migración, racismo y humor. Estereotipos sobre el migrante andino en las historietas del Perú oligárquico ${ }^{1}$
}

Luis Rodríguez

doi: $10.46476 /$ ra.v1i2.32

\section{Resumen}

La tesis estudia cómo se reprodujeron y fortalecieron los estereotipos sobre el migrante andino en un contexto de masiva migración durante los años cincuenta en Lima. Para ello, proponemos a la historieta como un artefacto cultural que permite conocer los discursos racistas de la época. En ese sentido, hemos estudiado a la historieta durante sus primeros diez años de publicación que coincidieron con el Perú oligárquico, hemos resaltado - desde el concepto de la etnicidad- aquellas viñetas que manifiestan un estereotipo que tiene como base la deformación intencional de la cultura. Así, la caricatura Serrucho transmitió la percepción racista limeña y los estereotipos que le imponían al migrante andino, estos deformaban sus características culturales como las costumbres, gustos, hábitos, conducta y moral, lo que generó la creación de una imagen inamovible e inalterable de lo que se supone era un migrante.

1. Tesis para optar por el título de Magíster en Historia (Rodríguez, 2019) 


\section{Introducción}

El Perú tiene un alto índice de prácticas racistas. La impunidad con la cual actúan los operadores de justicia ante las denuncias por discriminación es preocupante, y el Estado peruano poco puede hacer para combatir una práctica que se asume como un hecho cotidiano sin sanción, como sentenciaba Flores Galindo (2015). Así, el racismo está presente históricamente no solo en la obra de intelectuales o en los discursos y proyectos políticos, sino que puede encontrarse en el entramado de la vida misma. En los años cincuenta, las bromas callejeras, los refranes, las caricaturas e historietas de diarios articulaban y condicionaban una visión estereotipada y racista sobre el migrante andino. En un país cuya tasa de alfabetismo fue precaria, es importante tomar en cuenta cómo los discursos racistas se manifestaron y enunciaron a través de artefactos culturales no escritos, aparentemente inofensivos, pero eficaces a la hora de transmitir estereotipos sobre los grupos sociales debido a su popularidad, humor y consumo. Ahí radica la importancia de una historieta como Serrucho, la cual se difundió con un inusitado éxito durante los gobiernos de Manuel Odría y Manuel Prado Ugarteche.

\section{Problema y metodología}

El problema de la investigación de la tesis consistió en entender cómo la historieta Serrucho fue un espacio humorístico y visual que articuló, reprodujo y fortaleció los discursos oligárquicos sobre raza y los estereotipos sobre el migrante andino que circulaban en Lima. En efecto, en la época se asumía que el hombre andino poseía rasgos identificables de su personalidad y cultura; en esencia, eran por naturaleza desaseados, violentos, viciosos, lascivos y delictivos. Estas nociones estaban presentes en una gran variedad de fuentes escritas como narrativa literaria, ensayos históricos u obras criminológicas; sin embargo, fueron popularizados masivamente a través de las historietas de la prensa.

Metodológicamente, esta tesis analizó la tira cómica Serrucho entre 1952 y 1962. Se estudiaron todas las viñetas publicadas en ese lapso y se destacaron aquellas que de forma manifiesta evidenciaban la transmisión de un estereotipo, entendiendo esta categoría a partir de la etnicidad, es decir, una valoración negativa de la cultura, hábitos y moral antes que del aspecto físico. Asimismo, seguimos las recomendaciones de Gantús (2010) para estudiar una historieta, ya que la entendemos como un lenguaje visual, donde cada viñeta es un universo de referencias simbólicas que pueden rastrearse en otro tipo de fuentes. Una vez identificados los distintos estereotipos que se reproducían en la historieta, los hemos clasificados de dos tipos; aquellos que describían deformemente la cultura del migrante andino, y aquellos que describían su supuesta conducta censurable. Los del primer tipo presentan el entorno y la cultura del migrante como su 
hábitat, origen, vestimenta, música, alimentos; los segundos imponían sobre el migrante una personalidad cuestionable como la lascivia, la violencia familiar, el alcoholismo, el desaseo, la fealdad, la indigencia, la incapacidad intelectual y la criminalidad. Posteriormente, hemos recurrido a otras fuentes para rastrear los orígenes de estos estereotipos tales como literatura, tratados científicos, ensayos políticos, prensa, otras caricaturas, etc. Sin embargo, la investigación no se limita al análisis del discurso de la historieta, sino que toma en cuenta los procesos sociales, políticos y culturales de la época para entender por qué apareció la historieta, por qué estaba provista de estereotipos y por qué fue tan popular.

En la investigación usamos las propuestas teóricas de De la Cadena (2001), Stallaert (2003), Appelbaum (2003) y Elías (1998). En efecto, nos enfocamos en un determinado tipo de discriminación, aquel que operaba sobre criterios culturales y no por el color de la piel, que en la época era un asunto ambiguo para el caso de los migrantes andinos. Como propone Cosamalón (2017), el color de la piel antes que definir a un grupo étnico es una puerta de entrada a otros significados de carácter cultural. De la Cadena llamó a este proceso «racialización de la cultura» en tanto se entendía que una comunidad étnica no estaba ligada solo a rasgos biológicos, sino también a un lenguaje, una cultura e incluso al espíritu de las personas. De tal forma que en el Perú de los cincuenta, las consideraciones despreciativas sobre el indígena buscaban estereotipar ante todo sus manifestaciones culturales (alimentos, música, vestimenta) y al mismo tiempo se le imponía una personalidad y conducta reprobable. Según Stallaert, los elementos culturales de las comunidades étnicas -en ciertos contextos políticos- se convertían en «marcadores culturales» que servían para diferenciar a los grupos sociales y establecer una simbólica frontera con el otro, de tal manera que se recurría a estos distintivos para diferenciarse y discriminar. Estas consideraciones explican con precisión los procesos sociales que se vivió en Lima a mediados del siglo XX, una época de crecimiento urbano, migración masiva y ruptura de las jerárquicas estructuras sociales.

\section{Discusión y hallazgos}

Lima siempre tuvo ciclos dinámicos de movimiento, pero durante las décadas del 40 y 50 las migraciones se incrementaron exponencialmente. Existe una amplia literatura cuantitativa y cualitativa que brinda evidencias de este crecimiento demográfico, así como las causas estructurales del hecho. Nuestro interés es tomar atención en cómo esas migraciones no solo alteraron el diseño urbano de Lima sino también motivaron los discursos de políticos e intelectuales que entendieron el proceso a través de categorías discriminatorias. Los diarios de la época mencionaban «la avalancha serrana»; los políticos proponían leyes para impedir el ingreso de esos migrantes; los intelectuales decían que Lima se «provincializaba», y los caricaturistas reflejaron con humor esa experiencia migratoria a través de 
historietas que entendían al migrante en términos estereotipados. La migración cuestionó la capacidad del Estado para solucionar problemas sociales como la vivienda, el transporte y trabajo, por ello, las respuestas que se generaron fueron la informalidad, el subempleo y las barriadas, que en el discurso periodístico de la época eran llamadas «cinturones de miseria» o «cánceres sociales»; estos espacios, que eran el refugio de los migrantes, estaban desprovistos de servicios sociales y saneamiento, por ello fueron considerados lugares hacinados, sucios y malolientes, lo que fortalecía los prejuicios impuestos a sus pobladores.

Así, en este contexto de transformación urbana y social apareció la historieta Serrucho (1952) de David Málaga en el diario Última hora. Solo semanas antes, un senador había propuesto restringir el ingreso de provincianos a Lima debido a los males sociales que supuestamente traerían. La discusión que generó propuestas como estas y la situación misma evidencia que existía un diagnóstico común en la época el cual indicaba que Lima había cambiado ferozmente debido a la presencia migrante. Esto era ineludible, y los diarios de la época, lejos de ignorar a los migrantes, los incluyeron en el mercado de consumidores, difundieron noticias de sus pueblos y los representaron visualmente; por ello, en 1952 Última hora presentó su proyecto «Tiras cómicas $100 \%$ nacionales» en la cual se pretendía reflejar la variopinta composición social del país. Sin embargo, este reconocimiento se dio a través de categorías racistas donde se presentaba al migrante de forma humorística con estereotipos propios de la época.

La historieta estaba provista de estos prejuicios no solo por el racismo cotidiano que circulaba en el ambiente limeño, sino también debido a la naturaleza del diario. Última hora pertenecía al grupo de La Prensa que era propiedad del oligarca Pedro Beltrán, quien tuvo una activa participación como aliado y opositor de los gobiernos de Odría y Prado. Última hora inicialmente omitió cualquier comentario político sobre el régimen, y se enfocaba más en el entretenimiento. La publicación de historietas fue parte de esta línea periodística. Aun así, sus editoriales, artículos, noticias e historietas dialogan con el contexto social y entienden el fenómeno de la migración desde una posición intelectual vinculada a la oligarquía, que culturalmente se asumía en la época como limeña y criolla. Según el discurso hegemónico de la época, debido a las migraciones Lima se estaba «deslimeñizando».

Holt, Appelbaum, McPherson y Rosemblatt (2003) manifiestan que las identidades no son categorías abstractas, sino que poseen raza, género y clasificaciones sociales, ya que ello ayuda a identificar quién pertenece a una identidad y quién no. De ahí que la formación y enunciación de una identidad es un proceso que siempre señala al otro. La Lima de los 50 experimentó esa situación. Los intelectuales limeños empezaron a enunciar que la identidad limeña tenía sus orígenes en las costumbres coloniales, que la comida, música, costumbres y tradiciones «criollas» 
eran su distintivo cultural, y que el carácter de los limeños era el de ser jaraneros, palomilleros y donjuanescos. Estos discursos pueden rastrearse desde inicios del siglo XX, pero se intensificaron en un momento cuando la identidad limeña vio que se cuestionaban las estructuras jerárquicas y culturales de la sociedad. Así, aparecieron novelas, tradiciones, libros de estampas, películas y música, como manifestaciones que incidían en el carácter criollo de Lima y omitían la presencia andina. Esto es a lo que Elías (1998) llamaba la cohesión interna de los «establecidos» que frente a los «marginados» siempre usaran el armazón cultural del que disponen para crearse la imagen de gente superior y colocar estigmas y marcas a quienes no eran sus iguales.

Bajo los anteriores considerandos, los migrantes provincianos no solo no eran limeños, sino también se los reconocía como invasores, así los llamó Manuel Faura con su proyecto que les impedía el ingreso a Lima, y así fueron catalogados por los artículos que Caretas publicó en la época, en donde se recogían las quejas de limeños por la presencia andina en su fiesta de Amancaes. Intelectuales, periodistas, escritores y caricaturistas incidieron en la identidad limeña y contrapusieron culturalmente a los andinos; así enfrentaron los anticuchos y picarones contra el mote y las habas; la música criolla contra el huayno; la ropa elegante contra el chullo y poncho; un buen habla contra los «motes» lingüísticos; las peñas contra los coliseos; y la actitud vivaz contra la supuesta sumisión y personalidad huraña de los indígenas. Todas estas referencias fueron graficadas en las viñetas de Serrucho y motivaron la burla de los miles de sus lectores, ya que la historieta no creó ningún estereotipo, sino que tomó los que pululaban en el ambiente intelectual para difundirlas y fortalecerlas. La transmisión de estos prejuicios fue exitosa porque se presentaron en un medio visual y masivo, como una historieta que permitía que las caracterizaciones cómicas de los personajes pasaran como naturales, pues el sentido de deformidad usualmente no era detectado (Barbieri 1993).

El éxito en la difusión y popularización de estos estereotipos fue a causa de la naturaleza del diario emisor, Última hora. Aquel vespertino llegó a ser la publicación más leída de los cincuenta, pues tenía un tiraje de 100, 000 ejemplares. La popularidad del diario se debía a las innovaciones periodísticas que incluyeron el uso de la replana, los concursos y sorteos, la sección de espectáculos, la inclusión de noticias regionales y la constante comunicación que mantenía con sus lectores a partir de encuestas y publicación de cartas. Asimismo, el bajo costo del diario lo hacía accesible a los grupos populares, quienes a su vez tenían como motivación leer las tiras cómicas diarias como lo revelaron varias personas a través de una encuesta en la época. Los mismos libreros y quiosqueros notaban que el público limeño tenía una afición por leer historietas y tiras cómicas, por ello no fue extraño que los estereotipos que Serrucho transmitía en la historieta hayan sido interiorizados por su público lector. Además, como recuerda David 
Málaga, en la época muchas personas enviaban cartas a los caricaturistas, pedían saludos, daban ideas para incluir en las viñetas y algunos solicitaban autógrafos para un familiar a cambio de un regalo. La popularidad de Serrucho llevó a su autor a ser entrevistado por Caretas en 1961, y el mismo personaje fue utilizado como la imagen del migrante andino en un libro de tipos limeños, editado por Hugo Villasis en los setenta.

La influencia de Serrucho en sus lectores fue reconocida incluso por el Gobierno de las Fuerzas Armadas, ya que en los setenta identificaron cómo esta historieta transmitía consideraciones prejuiciosas de los migrantes en contraposición a la imagen del hombre andino que pretendían difundir. Asimismo, la popularidad de Serrucho alteró las formas de designación de la época, ya que la historieta no solo reflejó la experiencia de la migración, sino que también condicionó la forma en la cual los migrantes eran denominados. En efecto, en la época se usó el genérico "serrucho» para llamar a cualquier migrante; los diarios utilizaban el término y la evidencia demuestra que muchas personas usaban el apelativo para llamar a los que tenían orígenes provincianos. Serrucho pasó de sustantivo a adjetivo, y con él todos los estereotipos que transmitía se condensaron en la palabra, de tal forma, que ya no era necesario mencionar el prejuicio, pues ya estaba incluido en el término. Así, los diarios de la época mencionaban a los migrantes violentos, acosadores y alcohólicos solo como «serruchos»; el mismo proceso sufrieron las palabras con las que era asociado tales como «chontril» o «chontano». Incluso, los diccionarios de jergas de los cincuenta en adelante incluyeron estos términos como referencia y sinónimo de indígena. Fue gracias a eso que estas palabras que usualmente se usaban para ofender o denigrar nunca pasaron por un proceso de resignificación, pues siguieron connotando estigmas, prejuicios y consideraciones sociales, incluso hoy día.

En conclusión, Serrucho fue un espacio popular y eficaz que ayudó a difundir una serie de estereotipos sobre el migrante andino en un contexto de masivas migraciones que obligaron a la intelectualidad limeña a identificar en las costumbres y personalidad andinas, los elementos de su exclusión y discriminación, pues no correspondían con la identidad criolla y limeña. La tira cómica además alteró las formas en cómo identificar y nombrar un migrante convirtiéndose así no solo en el reflejo de una realidad, sino en un factor que ayudó a construirla. 


\section{Referencias bibliográficas}

Appelbaum, N., A. McPherson y K.A. Rosemblatt. (2003) «Introduction: Racial Nations» en Appelbaum, N., A. McPherson y K.A. Rosemblatt (eds). Race \& Nations in Modern Latin America (pp. 1-31). Chapel Hill and London: University of North Carolina Press.

Barbieri, D. (1993). Los lenguajes del comic. Barcelona: Paídos.

Cadena, M. (2001). Reconstructing Race: Racism, Culture and Mestizaje in Latin America. NACLA, Report on the Americas, 34 (6).

Cosamalón, J. (2017). El juego de las apariencias. La alquimia de los mestizajes y las jerarquías sociales en Lima, siglo XIX. Lima: Instituto de Estudios Peruanos/ El Colegio de México.

Elías, N. (1998). «Ensayo teórico sobre las relaciones entre establecidos y marginados» en La civilización de los padres y otros ensayos. Bogotá: Norma.

Flores-Galindo, A. (2015). Buscando un inca. Identidad y utopía en los andes. Lima: SUR.

Gantús, F. (2016). ¿Héroe o villano? Porfirio Díaz, claroscuros. Una mirada desde la caricatura política en Historia Mexicana, LXVI (1)

Rodríguez, L. (2019). El migrante estereotipado. Etnia y humor en Serrucho, 19501962. (tesis de maestría). Recuperado de http://tesis.pucp.edu.pe/repositorio/ handle/20.500.12404/15420.

Stallaert, C. (2003). «La cuestión conversa y la limpieza de sangre a la luz de las conceptualizaciones antropológicas actuales sobre la etnicidad» en Pere Joan I Tous y Heike Nottebaum (eds.), El olivo y la espada. Estudios sobre el antisemitismo en España (siglos XVI-XX). Tubingen: Max Niemeyer Verlag. 